\title{
Prognostic significance of retinoblastoma gene mutation in retinoblastoma eye with respect to pathological risk factors ${ }^{\star}$
}

\author{
Asad Aslam Khan ${ }^{1}$, Riffat Mehboob ${ }^{2}$, Mulazim Hussain Bukhari ${ }^{2}$ \\ ${ }^{1}$ Department of Ophthalmology, King Edward Medical University, Lahore, Pakistan; mulazim.hussain@gmail.com \\ ${ }^{2}$ Department of Pathology, King Edward Medical University, Lahore, Pakistan
}

Received 25 December 2012; revised 24 January 2013; accepted 10 February 2013

\section{ABSTRACT}

Retinoblastoma (Rb) was reported firstly by Benedict is the commonest pediatric intraocular malignant tumor in children younger than 5 years of age. The study was conducted to detect the RB-1 gene for prognostic evaluation in retinoblastoma and to see the frequency of RB-1 gene in our population. This was a retrospective descriptive analytical study. Five years biopsies (January, 2006 to December 2011) of the retinoblastoma, from the Pathology department, was retrieved to see optic nerve involvement in all the retrieved specimens. The study was taken to see the mutation of RB1 gene by immunohistochemistry and PCR. The study plan was approved from Institutional Review Board (IRB) of the University. All the cases showed positivity of abnormal Rb-1 gene proteins expression by Immunohistochemistry staining. On PCR, 51/52 (98\%) tumors expressed gene mutation as compared to $100 \%$ expression shown by IHC. Out of these, 28/51 (55\%) cases showed ONI and ODI with positivity for mutated RB gene. A positive association was seen among RB gene mutation with $O N I$ and $O D I(p=0.05)$. There were $33 / 51$ (65\%) cases who did not show any EOE but showed PCR positivity for RB gene mutation. While there were $18 / 51$ (35\%) cases who showed EOE and positivity of PCR for Rb-1 gene mutation and a positive association was seen with EOE and gene mutation $(p=0.005)$. The most common sequence of mutation was on 13 with 33 cases for double mutation, 12 cases for single and 6 patients for triple pattern of mutation. Most of the double and triple sequences of mu-

\footnotetext{
*The manuscript is the real aspect of Ph.D. Project of Asad Aslam Khan (Gene based study of prognostic evaluation of retinoblastoma of eye) and authors have no conflict of interest.
}

tations were associated with $O N I, O D I$ and EOE. We concluded that mutation of RB-1 gene is responsible in causation of the tumors with a positive association with tumor size and tumor extension (optic nerve, and extraocular extension), and mutation affects patients with all ages, both gender and unilateral and bilateral tumors.

Keywords: Retinoblastoma; RB-1 Gene; Optic Nerve; Optic Disc; Extra-Occular Extention; PCR; Immunohistochemistry; Sequencing

\section{INTRODUCTION}

Retinoblastoma $(\mathrm{Rb})$, the most common primary ocular malignancy of childhood, often related to mutations in the RB1 gene, arising from retina, generally affects children under the age of 6 . It can affect one or both eyes. A whiteness in the pupil or squint, usually alerts the parent or pediatrician to possible diagnosis [1].

Genetic mutation involving "Retinoblastoma gene 1 (Rb1) at chromosome 13 affects has a significant role in its etiology [2]. RB inherited as autosomal dominant trait, with $40 \%$ of worldwide cases belonging to this category, needs mutation in both the alleles for the disease to occur [3]. Irrespective of the gender and race the mean ageadjusted incidence of RB in the USA is 11.8 per million children aged 0 - 4 years [4].

Retinoblastoma gene mutations are highly heterogeneous, with a wide-range, from $5.5 \%$ to $94.8 \%$, depending upon the patient selection criteria (unilateral, bilateral, familial, and/or sporadic cases) and the screening techniques $[5,6]$. Individuals carrying a germline mutation are predisposed within the first 2 years of life to multifocal bilateral tumors, and later in adulthood to bone and connective tissue tumors [7].

Successful treatment of retinoblastoma depends upon its early detection and intervention [4]. However, $87 \%$ of the children who become the victim of this disease 
worldwide die, mostly in developing countries. In developed countries, $97 \%$ of those who do live have moderate to severe visual impairment or the child may lose one or both eyes [8].

The study was conducted to detect the RB-1 gene for prognostic evaluation in retinoblastoma and to see the frequency of RB-1 gene in our population.

\section{MATERIAL AND METHODS}

This was a retrospective descriptive analytical study. The records of the Institute of Ophthalmology, King Edward Medical University/Mayo hospital, Lahore. Pakistan for more than 909 cases of orbital lesions January 2006-December 2011 was analyzed. Five years biopsies of the retinoblastoma, from the Pathology department, were retrieved to see optic nerve involvement in all the retrieved specimens. The study was taken to see the mutation of RB1 gene by immunohistochemistry and PCR. Their specimens/slides were reanalyzed for genetic detection in the pathology department and studied for the prognostic factor by immunohistochemistry and PCR.

\subsection{Study Design}

Analytical Descriptive.

\subsection{Study Population}

Patients with Retinoblastoma who visited the Institute of Ophthalmology from 2006 to 2011.

\subsection{Study Settings}

Patients who came to Ophthalmology Department, Mayo Hospital, King Edward Medical University, Lahore.

\subsection{Inclusion Criteria}

Pakistani citizens.

All age groups.

Both male and female.

Patient with orbital lesions.

\subsection{Exclusion Criteria}

Patients with incomplete history.

Tumors other than Retinoblastoma.

\subsection{Approval of Ethical Committee:}

The study plan was approved from ethical committee of King Edward Medical University.

\subsection{Detection of Rb Protein by Immunohistochemistry $[9,10]$}

Formalin-fixed sections of each specimen was stained with hematoxylin/eosin and examined microscopically to confirm the presence of tumor cells. Immunohistochemistry was performed on 5 um formalin-fixed sections using the $\mathrm{Rb} 1$ anti $\mathrm{Rb}$ (DAKO Dilution 1/50) antibody and the avidin-biotin complex (ABC) technique. After incubating of sections with the above antibodies for 45 minutes at room temperature, staining with LSAB2 Kit (DAKO) and using of DAB was followed. Positive and negative controls were applied in each series. Staining will be repeated in all 10 samples for two times in two different series, but in equal conditions, and the results were similar. Serial sections were treated with Mel-5 an antibody to human melanosomes, as a negative control. All sections were counterstained with methylene blue to verify presence of intact nuclei.

\subsection{Grading of IHC}

Nuclear staining for $\mathrm{Rb}$ protein as well as cytoplasmic staining of tumoral cells for RB-1 was reported as follows:

1) $0 \%-10 \%=\mathrm{Neg}$;

2) $10 \%-30 \%=1+/$

3) $30 \%-60 \%=2+/$;

4) $60 \%-100 \%=3+$.

\subsection{Molecular Analysis}

Genomic DNA was isolated from formalin fixed tissues of retinoblastoma tumors using a commercial DNA isolation kit (Gentra, Minneapolis, MN), following the manufacturer's instructions including proteinase- $\mathrm{K}$ digestion followed by salting out of DNA. A nested polymerase chain reaction (PCR) protocol was established with two sets of primers designed to amplify exon 27 of the RB1 gene and its vicinity region and tested on single lymphocytes from the couple. Screening of germline mutations in the RB1 gene was performed with PCRdirected sequencing of the promoter and the 27 coding exons, and their flanking intronic regions, using the primers described by Abouzeid et al. [8]. PCR reactions were performed in a thermal cycler (ABI 2700), in a total volume of $15 \mu \mathrm{l}$ containing 25 - $50 \mathrm{ng}$ of genomic DNA, 3 picomoles of each primer, and $7.5 \mu$ lof master mix $2 \times$ (AmpliTaq Gold 360 Master Mix; Applied Biosystems, Foster City, CA). Reactions were performed for $35 \mathrm{cy}$ cles of $94^{\circ} \mathrm{C}$ for $1 \mathrm{~min}$, annealing at the specific temperature for $1 \mathrm{~min}, 72^{\circ} \mathrm{C}$ for $1 \mathrm{~min}$, and a final extension step at $72^{\circ} \mathrm{C}$ for $7 \mathrm{~min}$. After the unincorporated deoxynucleoside triphosphates and primers were removed using Exonuclease I and shrimp alkaline phosphatase (ExoSAP-IT PCR Purification Kit, GE Healthcare, UK), the PCR products were directly sequenced using the ABI BigDye Terminator v 3.1 Sequencing Standard Kit (Applied Biosystems, Foster City, CA) and run on an ABI 3130 Genetic Analyzer. The sequence data were analyzed 
by comparison to the consensus sequence of the RB1 gene (GenBank L11910.1) using ABI SeqScape v2.5 software.

Sequences were aligned using the Chromasversion 2.23 (Technelysium, Tewantin, Australia). Screening for large deletions was performed by haplotype analysis using RB1 flanking microsatellites D13S161, S13S164, D13S153, D13S1307, and D13S273. One primer was fluorescently labeled, and the product was separated on an automated sequencer (ABI XL3100; Applied Biosystems). Additional information about mutations and variants was obtained from the RB1 gene database. Primers used for Gene analysis of RB-1 gene (Annex I)

\subsection{Statistical Analysis}

All collected data was entered in SPSS version 17 and data was analyzed by using the same software. The qualitative data will be presented in form of frequency table (\%) and appropriate graphs. The quantitative data was presented in form of mean \pm S.E. We 1 also use Standard Deviation to see the variability of the quantitative data. The following analysis was used to meet the objectives of the study. We calculate prevalence for descriptive study design and Chi-square analysis will be used to see the association between qualitative data. Fisher exact test will was used when expected count was less than 5 . A p-value less or equal to 0.05 will be considered as significant.

\section{RESULTS}

The minimum age was 1 year while maximum age was 10 years (Age Range 1 - 10 years) while the mean age was $3.54 \pm 1.686$ years. The maximum numbers of cases with Retinoblastoma eye were of 3 years 18/52 $(34.6 \%)$ while one case was found with seven years and 10 years group (Figure 1). There were 15 cases of bilateral retinoblastoma and 37 cases with unilateral neoplasms. The age range of bilateral tumors was $2-6$ years while the range in unilateral tumor was 1 - 10 years (Table 1). There were 32 female and 20 males suffering from Retinoblastoma and male to female ratio was 1:1.5. Male were $38 \%$ and females were $61.5 \%$ (Table 1, Fig- ure 2A). Table 2 shows frequency of unilateral and bilateral tumors in our patients.

\section{Immunohistochemistry and PCR Expression for RB Gene (Tables 3 \& 4 and Figures 2 \& 3)}

All the cases showed positivity of abnormal Rb-1 gene proteins expression by Immunohistochemistry staining. There were $23 / 52(44 \%)$ cases who showed no ONI. While there were $29 / 52(56 \%)$ cases who showed ONI with and positivity of IHC for abnormal Rb-1 gene proteins expression and this was a positive for ONI ( $\mathrm{p}=$ $0.001)$. There was positive association of abnormal $\mathrm{Rb}-1$ gene proteins expression for ONI on IHC.There were $24 / 52(46 \%)$ cases who did not show any invasion of tumor for $O D I$ but showed IHC positivity for abnormal $\mathrm{Rb}-1$ gene proteins expression. While there were 28/52 (54\%) cases who showed ODI and positivity of IHC for abnormal Rb-1 gene proteins expression and there was a positive relationship for $O D I(p=0.001)$ and abnormal Rb-1 gene proteins expression on IHC. All the cases showed positivity of abnormal $\mathrm{Rb}-1$ gene proteins expression by Immunohistochemistry staining. There were $34 / 52$ (65\%) cases who showed no EOE but showed IHC positivity. While there were $18 / 52$ (35\%) cases who

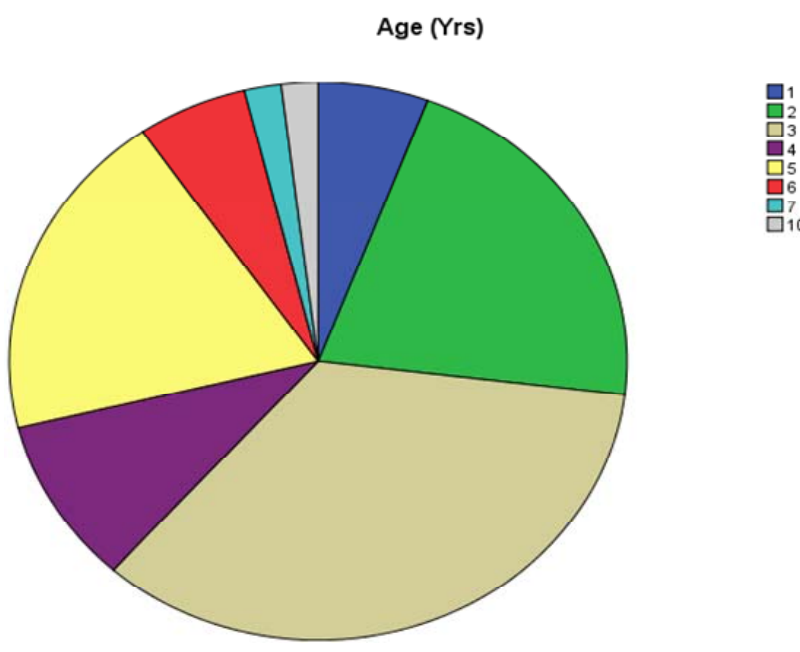

Figure 1. Graph.1: showing statistical Range age of frequency of different cases with retinoblastoma ( 1 - 10 years range).

Table 1. Age Distribution of Unilateral and Bilateral Retinoblastoma.

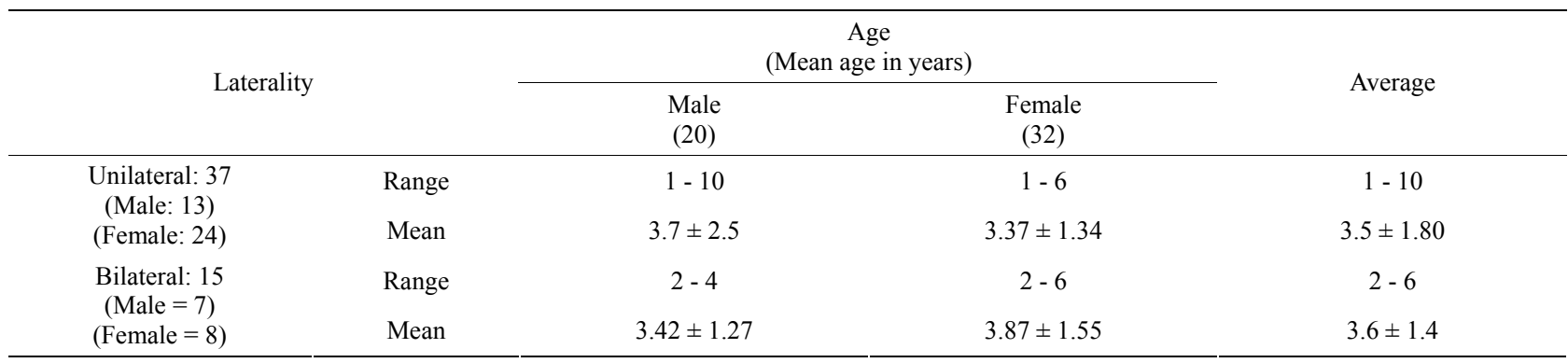




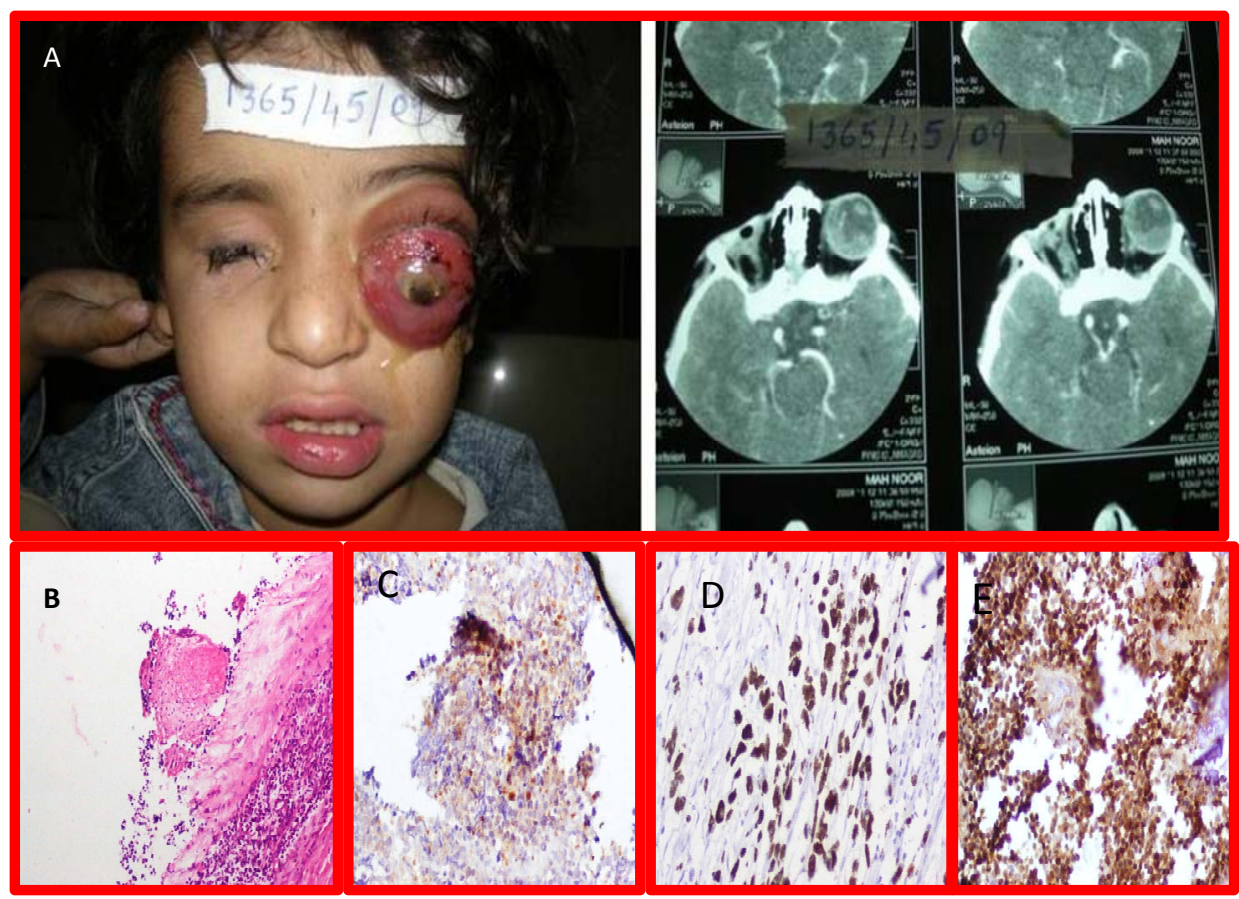

Figure 2. A: Gross Picture of Retinoblastoma with Proptosis of Rt Eye (Unilateral Retinoblastoma) with B Scan with bilateral tumors; B: Photomicrographs of -RB-1 gene IHC of Retinoblastoma showing grade II positivity. (H\&E stain 20×); C: RB-1 gene IHC of Retinoblastoma showing grade III positivity. (H\&E stain $20 \times$ ); D: RB-1 gene IHC of Retinoblastoma showing grade IV positivity. (H\&E stain $20 \times$ ); E: Arrow showing Retinoblastoma involving Sclera and optic nerve $(\mathrm{H} \& \mathrm{E} 10 \times)$.

Table 2. Frequency of retinoblastoma in both eyes (side involvement).

\begin{tabular}{ccc}
\hline Side of Involvement & Frequency & Percent \\
Unilateral & 37 & 71.2 \\
Bilateral & 15 & 28.8 \\
Right Eye & 20 & 38.5 \\
Left Eye & 17 & 32.7 \\
Both Eye & 15 & 28.8 \\
Total & 52 & 100.0 \\
\hline
\end{tabular}

showed EOE and positivity of IHC for abnormal Rb-1 gene proteins expression and this was a positive association for $E O E(\mathrm{p}=0.002)$ and abnormal $\mathrm{Rb}-1$ gene proteins expression. On PCR, 51/52 (98\%) tumors expressed gene mutation as compared to $100 \%$ expression shown by IHC. Out of these, 28/51 (55\%) cases showed ONI and $O D I$ with positivity for mutated RB gene. A positive association was seen among RB gene mutation with $O N I$ and $O D I(\mathrm{p}=0.05)$. There were $33 / 51(65 \%)$ cases who did not show any EOE but showed PCR positivity for RB gene mutation. While there were $18 / 51$ (35\%) cases who showed EOE and positivity of PCR for Rb-1 gene mutation and a positive association was seen with $E O E$ and gene mutation $(p=0.005)$. The most common sequence
Table 3. Association of gene mutation and optic nerve, optic disc invasion and extra-orbital extension.

\begin{tabular}{ccc}
\hline $\begin{array}{c}\text { Optic Nerve } \\
\text { Invasion }\end{array}$ & ${ }^{*}$ IHC Positive & ${ }^{* *}$ PCR Positive \\
\hline No & 23 & 23 \\
Yes & 29 & 28 \\
Total & 52 & 51 \\
${ }^{*}(\mathrm{p}=0.001),{ }^{* *}(0.05)$ & & \\
\hline Optic Disc & IHC \\
Invasion & 24 & 23 \\
No & 28 & 28 \\
Yes & 52 & 51 \\
Total & & \\
${ }^{*}(\mathrm{p}=0.001),{ }^{* *}(0.05)$ & & 33 \\
\hline Extra-Orbital Extension & 34 & 18 \\
\hline No & 18 & 51 \\
Yes & 52 & \\
Total & & \\
${ }^{*}(\mathrm{p}=0.001),{ }^{* *}(0.005)$ & & \\
\hline
\end{tabular}

of mutation was on exon 17, 20, 24 and 13 while few other mutations were also detected. 33 cases showed double sequence of mutation while 12 expressed single and 6 showed triple pattern of mutation. Most of the double and triple sequences of mutations were associated with ONI, ODI and EOE (Tables 3 and 4, Figures 2A-E 
Table 4. Association of Gene mutation and optic nerve, optic disc and extra ocular extension.

\begin{tabular}{|c|c|c|c|c|c|}
\hline Name of axons & Mutation Pattern Codons (bp) & $\begin{array}{l}\text { No of cases } \\
(\mathbf{n}-\mathbf{5 1})\end{array}$ & $\begin{array}{c}\text { Optic nerve Invasion } \\
(28 / 51)\end{array}$ & $\begin{array}{c}\text { Optic Disc Invasion } \\
(28 / 51)\end{array}$ & $\begin{array}{c}\text { Extra-Ocular Extension } \\
(\mathbf{1 8 / 5 1 )}\end{array}$ \\
\hline 4 & $\begin{array}{c}265 \mathrm{bp} \\
\text { g.41941_41942-insertion at T }\end{array}$ & 1 & 0 & 0 & 0 \\
\hline 9 & $\begin{array}{c}202 \mathrm{bp} \\
\text { frameshift } \\
156840 \mathrm{~T}>\mathrm{C}\end{array}$ & 7 & 2 & 2 & 0 \\
\hline 10 & $\begin{array}{c}95 \mathrm{bp} \\
\mathrm{A}>\mathrm{G} \text { transitions }\end{array}$ & 4 & 2 & 2 & 0 \\
\hline 13 & $\begin{array}{c}490 \mathrm{bp} \\
\text { frameshift } \\
\text { g. } 162021 \mathrm{G}>\mathrm{T}\end{array}$ & 10 & 3 & 3 & 3 \\
\hline 17 & $\begin{array}{c}354 \mathrm{bp} \\
\text { frameshift } \\
\text { g. } 78250 \mathrm{C}>\mathrm{T} \text { c. } 1666 \mathrm{C}>\mathrm{T}\end{array}$ & 32 & 12 & 12 & 6 \\
\hline 20 & $\begin{array}{c}326 \mathrm{bp} \\
156837 \_156840 \text { delAAGT }\end{array}$ & 23 & 8 & 8 & 4 \\
\hline 24 & $\begin{array}{c}165 \mathrm{bp} \\
\text { g.170374_170377delTCTT } \\
\text { c.2492_2495delTCTT }\end{array}$ & 17 & 1 & 1 & 4 \\
\hline 25 & $\begin{array}{c}248 \mathrm{bp} \\
\text { T-to-G transversion }\end{array}$ & 1 & 0 & 0 & 1 \\
\hline 27 & $326 \mathrm{bp}$ & 1 & 0 & 0 & 0 \\
\hline & Single mutation & 12 & 6 & 6 & 4 \\
\hline \multicolumn{2}{|c|}{ Double Mutation (double mutation) } & 33 & 18 & 18 & 12 \\
\hline \multicolumn{2}{|c|}{ Triple Mutation (complex deletion insertion) } & 6 & 4 & 4 & 2 \\
\hline
\end{tabular}

and Figures 3(a)-(c)).

\section{DISCUSSION}

In United Kingdom, most children with Retinoblastoms are diagnosed before the age of five years. Bilateral cases usually present within the first year with the average age at diagnosis being 9 months and age of unilateral cases peaks between 24 and 30 months [2].

The Rb1 gene is the first cloned tumor suppressor gene. As a negative regulator of the cell cycle, Rb1 gene could maintain a balance between cell growth and development through binding to transcription factors and regulating the expression of genes involved in cell proliferation and differentiation [2]. "The $\mathrm{Rb}$ gene product is a phosphoprotein that is expressed in most normal cells of vertebrates. $\mathrm{Rb}$ acts as a tumor suppressor by providing a cell cycle checkpoint between the G1 and S phases. The active, underphosphorylated form of $\mathrm{Rb}(\mathrm{Rb}$ or $\mathrm{pRb})$ is primarily found in resting or fully differentiated cells. The activity of $\mathrm{Rb}$ is negatively regulated by cyclin dependent kinases, which phosphorylate $\mathrm{Rb}$ in late $\mathrm{G} 1$. Thus, the hyperphosphorylated form ( $\mathrm{ppRb}$ ) is primarily found in proliferating cells. pRB inactivation is a critical step leading to S-phase commitment at the G1 checkpoint of the cell cycle" $[11,12]$. In children with the heri- table genetic form of $\mathrm{Rb}$, there is a mutation on chromosome 13, called the retinoblastoma 1 (Rb1) gene [2]. Several lines of evidence indicate that mutational inactivation of both alleles of the RB gene is required for retinoblastoma genesis. The structural analysis presented herein was undertaken to provide a framework for characterizing these mutations. We detected RB gene altered proteins products by IHC and pattern of mutation on coding strand of exon by PCR.

All the cases $(100 \%)$ showed positivity of abnormal Rb-1 gene proteins expression by Immunohistochemistry staining. There were $34 / 52(65 \%)$ cases who showed no EOE but showed IHC positivity. While there were 18/52 (35\%) cases who showed EOE. RB expression was significantly associated with $E O E(\mathrm{p}=0.002)$ and abnormal $\mathrm{Rb}-1$ gene proteins expression. These findings are consistent with Yun et al. who described that patients with sporadic unilateral $\mathrm{Rb}$, both $\mathrm{Rb} 1$ gene mutations occur in somatic cells and are associated with retinoblastoma and also have an increased risk of tumors outside the eye (second cancer). Almost all patients with sporadic $\mathrm{Rb}$ are bilateral and virtually all patients with familial $\mathrm{Rb}$ are heterozygous for Rb1 gene mutations that cause predisposition to $\mathrm{Rb}$ (hereditary $\mathrm{Rb}$ ). In families, $\mathrm{Rb}$ predisposition is transmitted as an autonomic dominant trait [13-15]. 


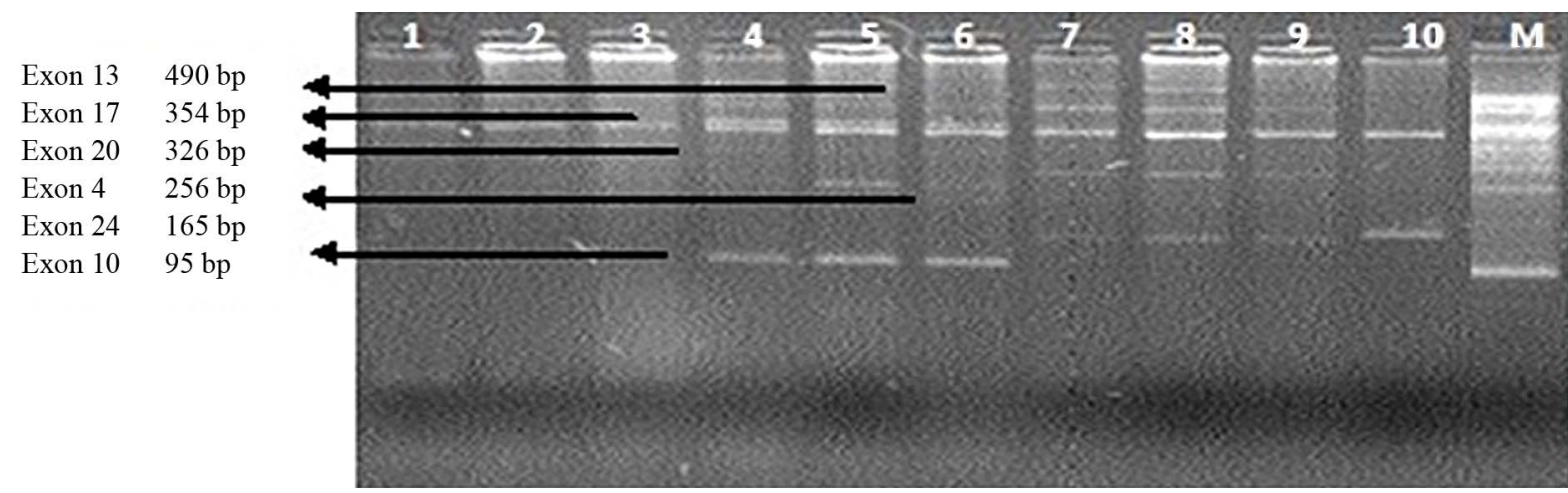

(a)

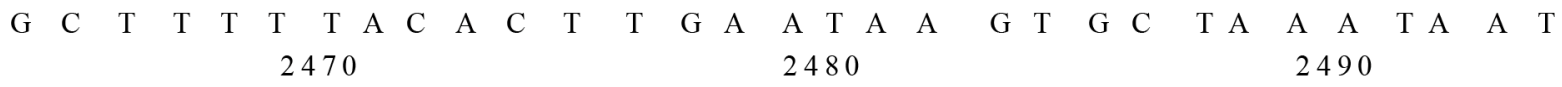

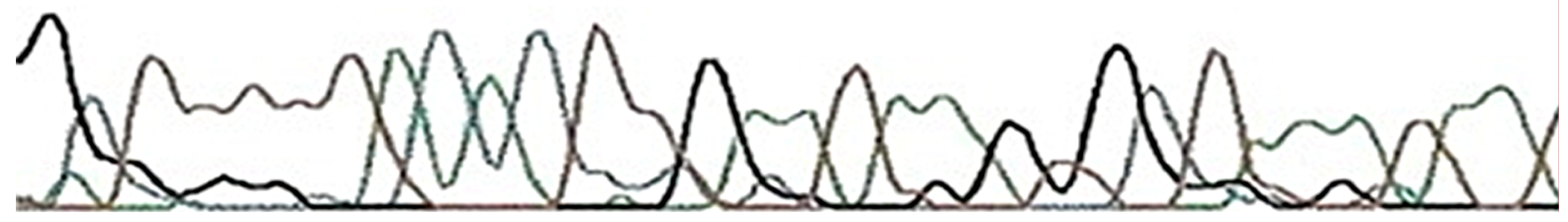

(b)

$\begin{array}{llllllllllllllllllllllllllllllll}\mathrm{T} & \mathrm{C} & \mathrm{T} & \underset{162021}{\mathrm{G}} \mathrm{T} & \mathrm{A} & \mathrm{C} & \mathrm{A} & \mathrm{G} & \mathrm{A} & \mathrm{G} & \mathrm{A} & \mathrm{A} & \mathrm{A} & \mathrm{A} & \mathrm{A} & \mathrm{C} & \mathrm{T} & \mathrm{T} & \mathrm{T} & \mathrm{A} & \mathrm{T} & \mathrm{T} & \mathrm{C} & \mathrm{T} & \mathrm{T} & \mathrm{A} & \mathrm{G} & \mathrm{A} & \mathrm{G} & \mathrm{G} & \mathrm{C} & \mathrm{T}\end{array}$

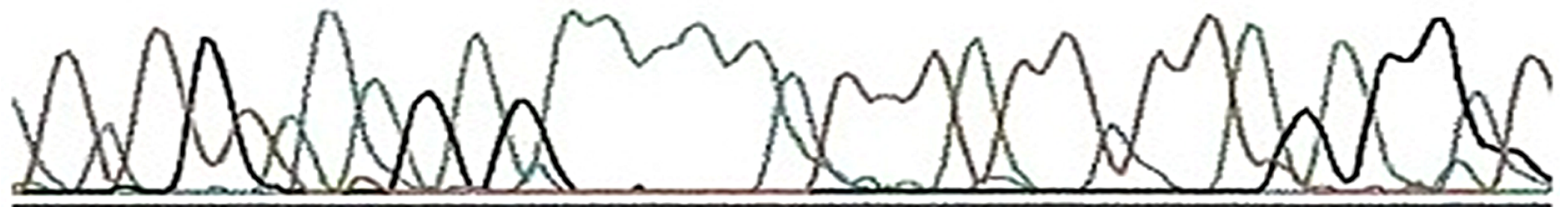

(c)

Figure 3. (a) Gel Photos of PCR, in Lane 1, -10 exon 17 mutation is seen. In lane 4, 5 \& 7 exon 13, mutation is also seen, In lane 5 exon 4265 bp and exon 24 is also noted n lane 8, 9, \& 10 exon 24 is also seen; (b) Sequence of mutation on Exon 24; (c) Sequence of mutation on Exon 33.

On PCR, 51/52 (98\%) tumors expressed gene mutation as compared to $100 \%$ expression shown by IHC. Out of these, 28/51 (55\%) cases showed ONI and ODI with positivity for mutated RB gene. A positive association was seen among RB gene mutation with $O N I$ and ODI $(\mathrm{p}=0.05)$. There were $33 / 51(65 \%)$ cases who did not show any EOE but showed PCR positivity for RB gene mutation. While there were $18 / 51$ (35\%) cases who showed EOE and positivity of PCR for Rb-1 gene mutation and a positive association was seen with EOE and gene mutation $(\mathrm{p}=0.005)$. Our results are consistent with Eagle et al, their harbor mutations in both copies of the RB1 gene and associated with uveal invasion and retrolaminar optic nerve invasion $[5,16,17]$. Laurie et al. proved this association at molecular basis, and their "detailed analysis of these cells as they were propagated in culture from the primary tumor shows that changes in cadherin-mediated cell adhesion are associated with retinoblastoma invasion of the optic nerve prior to metastasis. In addition, the same changes in cadherin-mediated cell adhesion correlate with the invasive properties of the human retinoblastoma cell lines isolated decades ago, providing a molecular mechanism for these earlier observations" [18]. In another study, it was seen that relating the RB gene expression with the clinico-pathologic features of the tumor tissues, and found that the tumor with invasion of choroid, optic nerve and retinal pigment epithelium, had relatively higher gene expression, when 
compared with the tumor with only choroidal invasion [19].

In another animal study, to generate animal models of retinoblastoma that closely resemble metastatic and nonmetastatic human disease for the purposes of examining tumor biology and developing alternate treatments, human retinoblastoma cell lines were injected into the vitreal cavities of immunodeficient mice, they proved that RB mutation was associated with histological criteria for poor prognosis like ONI and distance metastasis [20].

According to Lohmann et al. (2010), molecular genetic testing of the RB1 gene in white blood cell DNA is available in clinical laboratories and can identify a germline mutation in $90 \%-95 \%$ of individuals with a hereditary predisposition to RB [13]. In our study, we deselected $98 \%$ - 100\% mutation by PCR and IHC respectively, on tumor tissues.

Constitutional mutations of the RB1 gene are associated with a predisposition to retinoblastoma. It is essential to identify these mutations to provide appropriate genetic counseling in retinoblastoma patients [21]. Sequence analysis is used to identify small deletions, insertions, and base substitutions in exons and splice site consensus regions which account for about $70 \%$ of oncogenic RB1 mutations [14,22].

By using exon-by-exon analysis, the RB1 mutations were first screened in tumor DNA, we found that the most common sequence of mutation were seen on coding region. It was seen on exon 17 (354 bp), 20 (326 bp), 24 (165 bp) and 13 (490 bp) while few other mutations were also detected. 33 cases showed double sequence of mutation while 12 expressed single and 6 showed triple pattern of mutation. Most of the double and triple sequences of mutations were associated with ONI, ODI and EOE. In a study it was seen that by gels, coding strand of exon 20 and 14 showed mutation sites [23]. Our findings are also consistent with Shimizu et al. (1994), who found where the SSCP analysis of exon 13 shows an abnormal banding pattern in tumor DNA of patients with Retinoblastoma [24].

Summary: RB-1 gene was detected in 98\% - 100\% tumors and a positive association was seen with tumor size and tumor extension (optic nerve, and extraocular extension). No Association was see with age, gender and laterality of the tumors. The most common sequence of mutation was on 13 with 33 cases for double mutation, 12 cases for single and 6 patients for triple pattern of mutation. Most of the double and triple sequences of mutations were associated with ONI, ODI and EOE.

\section{AUTHOR CONTRIBUTION}

Khan AA, conceived of the study, analyzed the data and participated in the redaction of the manuscript, con- ducted pathological analyses. Mahboob R gave analytical support for all the analysis. Bukhari MH, Supervised the research project, read the article and made possible language changes. All authors read and approved the final manuscript.

\section{ACKNOWLEDGEMENTS}

We are thankful for Dr. Rubina Ghani for helping us is PCR and sequencing the type of mutation.

\section{REFERENCES}

[1] Abidi, O., Knari, S., Sefri, H., Charif, M., Senechal, A., Hamel, C., et al. (2011) Mutational analysis of the RB1 gene in Moroccan patients with retinoblastoma. Molecular Vision, 17, 3541-3547.

[2] Yun, J., Li, Y., Xu, C.T. and Pan, B.R. (2011) Epidemiology and $\mathrm{Rb} 1$ gene of retinoblastoma. International Journal of Ophthalmology, 4, 103-109.

[3] Knudson Jr., A.G. (1971) Mutation and cancer: Statistical study of retinoblastoma. Proceedings of the National Academy of Sciences of the United States of America, 68, 820-823. doi:10.1073/pnas.68.4.820

[4] Broaddus, E., Topham, A. and Singh, A.D. (2009) Incidence of retinoblastoma in the USA: 1975-2004. The British journal of Ophthalmology, 93, 21-23. doi:10.1136/bjo.2008.138750

[5] Rushlow, D., Piovesan, B., Zhang, K., Prigoda-Lee, N.L., Marchong, M.N., Clark, R.D., et al. (2009) Detection of mosaic RB1 mutations in families with retinoblastoma. Human Mutation, 30, 842-851. doi:10.1002/humu.20940

[6] Abouzeid, H., Munier, F.L., Thonney, F. and Schorderet, D.F. (2007) Ten novel RB1 gene mutations in patients with retinoblastoma. Molecular Vision, 13, 1740-1745.

[7] Moll, A.C., Imhof, S.M., Meeteren A.Y.S.-V., Kuik, D.J., Hofman, P. and Boers, M. (2001) Second primary tumors in hereditary retinoblastoma: A register-based study, 19451997: Is there an age effect on radiation-related risk? Ophthalmology, 108, 1109-1114. doi:10.1016/S0161-6420(01)00562-0

[8] Sovinz, P., Urban, C., Lackner, H., Benesch, M. and Langmann, G. (2006) Retinoblastoma: A proposal for a multimodal treatment concept for intraocular retinoblastoma in Austria. Wiener Klinische Wochenschrift, 118, 22 30. doi:10.1007/s00508-005-0503-Z

[9] Kumamoto, H. and Ooya, K. (2006) Immunohistochemical detection of retinoblastoma protein and E2 promoterbinding factor-1 in ameloblastomas. Journal of Oral Pathology \& Medicine, 35, 183-189. doi:10.1111/j.1600-0714.2006.00381.x

[10] Massaro-Giordano, M., Baldi, G., De Luca, A., Baldi, A. and Giordano, A. (1999) Differential expression of the retinoblastoma gene family members in choroidal melanoma: Prognostic significance. Clinical Cancer Research, 5, 1455-1458.

[11] Bignon, Y.J., Chen, Y., Chang, C.Y., Riley, D.J., Windle, J.J., Mellon, P.L., et al. (1993) Expression of a retino- 
blastoma transgene results in dwarf mice. Genes \& Development, 7, 1654-1662. doi:10.1101/gad.7.9.1654

[12] Cance, W.G., Brennan, M.F., Dudas, M.E., Huang, C.M. and Cordon-Cardo, C. (1990) Altered expression of the retinoblastoma gene product in human sarcomas. New England Journal of Medicine, 323, 1457-1462. doi:10.1056/NEJM199011223232105

[13] Lohmann, D. (2010) Retinoblastoma. Advances in EXperimental Medicine and Biology, 685, 220-227. doi:10.1007/978-1-4419-6448-9 21

[14] Lohmann, D.R., Brandt, B., Hopping, W., Passarge, E. and Horsthemke, B. (1996) The spectrum of RB1 germline mutations in hereditary retinoblastoma. American Journal of Human Genetics, 58, 940-949.

[15] Chintagumpala, M., Chevez-Barrios, P., Paysse, E.A., Plon, S.E. and Hurwitz, R. (2007) Retinoblastoma: Review of current management. The Oncologist, 12, 12371246. doi:10.1634/theoncologist.12-10-1237

[16] Eagle Jr., R.C. (2013) The pathology of ocular cancer. Eye (London, England), 27, 128-136.

[17] Nichols, K.E., Walther, S., Chao, E., Shields, C. and Ganguly, A. (2009) Recent advances in retinoblastoma genetic research. Current Opinion in Ophthalmology, 20, 351355. doi:10.1097/ICU.0b013e32832f7f25

[18] Laurie, N., Mohan, A., McEvoy, J., Reed, D., Zhang, J., Schweers, B., et al. (2009) Changes in retinoblastoma cell adhesion associated with optic nerve invasion. Molecular and Cellular Biology, 29, 6268-6282. doi:10.1128/MCB.00374-09
[19] Vandhana, S., Lakshmi, T.S., Indra, D., Deepa, P.R. and Krishnakumar, S. (2012) Microarray analysis and biochemical correlations of oxidative stress responsive genes in retinoblastoma. Current Eye Research, 37, 830-841. doi:10.3109/02713683.2012.678544

[20] Chevez-Barrios, P., Hurwitz, M.Y., Louie, K., Marcus, K.T., Holcombe, V.N., Schafer, P., et al. (2000) Metastatic and nonmetastatic models of retinoblastoma. The American Journal of Pathology, 157, 1405-1412. doi:10.1016/S0002-9440(10)64653-6

[21] Houdayer, C., Gauthier-Villars, M., Lauge, A., PagesBerhouet, S., Dehainault, C., Caux-Moncoutier, V., et al. (2004) Comprehensive screening for constitutional RB1 mutations by DHPLC and QMPSF. Human Mutation, 23, 193-202. doi:10.1002/humu. 10303

[22] Richter, S., Vandezande, K., Chen, N., Zhang, K., Sutherland, J., Anderson, J., et al. (2003) Sensitive and efficient detection of RB1 gene mutations enhances care for families with retinoblastoma. American Journal of $\mathrm{Hu}$ man Genetics, 72, 253-269. doi:10.1086/345651

[23] Hogg, A., Onadim, Z., Baird, P.N. and Cowell, J.K. (1992) Detection of heterozygous mutations in the RB1 gene in retinoblastoma patients using single-strand conformation polymorphism analysis and polymerase chain reaction sequencing. Oncogene, 7, 1445-1451.

[24] Shimizu, T., Toguchida, J., Kato, M.V., Kaneko, A., Ishizaki, K. and Sasaki, M.S. (1994) Detection of mutations of the RB1 gene in retinoblastoma patients by using exonby-exon PCR-SSCP analysis. American Journal of $\mathrm{Hu}$ man Genetics, 54, 793-800. 